\title{
Wpływ funduszy Programu Operacyjnego Innowacyjna Gospodarka na rozwój polskiego sektora naukowego
}

\author{
Impact of the Innovative Economy Operational \\ Programme's Funding on the Development \\ of the Polish Scientific Sector
}

\begin{abstract}
Streszczenie: Polska jest jednym z najmniej innowacyjnych krajów w Unii Europejskiej. Najważniejszą z przyczyn takiej sytuacji jest chroniczne niedofinansowanie sektora naukowego - łączna suma państwowych wydatków na naukę, badania i rozwój nie przekracza 1\% PKB. Równie niewielka jest skala inwestycji w prace B+R wśród podmiotów gospodarczych. Innymi poważnymi przeszkodami we wzroście innowacyjności są także: koncentracja sektora naukowego na badaniach podstawowych, niewielka skala komercjalizacji wyników badań naukowych oraz słabe połączenia na linii nauka-gospodarka. Wraz z przystąpieniem Polski do Unii Europejskiej szansę na częściowe zniwelowanie wieloletnich zaległości w finansowaniu nauki dają fundusze strukturalne. Funkcjonujący od 2007 roku Program Operacyjny Innowacyjna Gospodarka (POIG) stał się głównym narzędziem współfinansowania projektów badawczo-rozwojowych i modernizacji infrastruktury naukowej zarówno państwowych jednostek badawczych, szkolnictwa wyższego, jak i przedsiębiorstw. Po niemal 5 latach funkcjonowania programu i biorąc pod uwagę zbliżające się zakończenie perspektywy finansowej 2007-2013, można pokusić się o próbę podsumowania wybranych elementów funkcjonowania Programu.

Celem opracowania jest odpowiedź na pytanie o rolę funduszy POIG w finansowaniu państwowego sektora naukowego w Polsce, zarówno w ujęciu regionalnym, jak i strukturalnym. Ważnym zagadnieniem pozostaje również kwestia proporcji środków przeznaczonych na badania podstawowe i aplikacyjne oraz wspieranie komercjalizacji wyników badań naukowych (np. inkubatory przedsiębiorczości). Ilościową analizę zawartych umów na dofinansowanie uzupełniają studia przypadku, przybliżające sytuację największych beneficjentów europejskich środków strukturalnych wśród polskich uczelni wyższych. Podjęta została też próba identyfikacji najważniejszych problemów pojawiających się przy korzystaniu ze środków unijnych.
\end{abstract}

Abstract: Poland is one of the least innovative states among the EU members. Chronic underfunding of the scientific sector - with gross expenditures on R\&D below $1 \%$ of the GDP - is the most important cause of such situation. The scale on private involvement in R\&D activities remains similarly low. Also, focus on basic research, low commercialization and weak science-industry links are major obstacles for the growth of innovativeness. 
After Poland's EU accession, European structural funding has given a chance of reducing the arrears in the financing of the scientific sector. The Innovative Economy Operational Programme (POIG), functioning since 2007, became the main tool for financing both R\&D projects and scientific infrastructure development in national research centers, higher education and private sector. After almost 5 years of the Programme's functioning and given the imminent end of the EU's 2007-2013 financial perspective, one can try to summarize the main effects of the Programme.

The aim of this paper is answering the question about the role of POIG in financing the scientific sector in Poland in both regional and sectoral approach. The amount of funding for basic and applied research and technology also remains an important question. The quantitative analysis of number, value and distribution of financing agreements is complemented by case studies, presenting the situation of major beneficiaries of EU funding among Polish higher education establishments. Finally, an attempt to identify the most important obstacles in using the EU funding for scientific sector is made.

Słowa kluczowe: finansowanie; fundusze UE; Polska; sektor naukowy

Key words: EU funds; financing; Poland; scientific sector

\section{WSTĘP}

Badania naukowe stanowią podstawę postępu, wpływającego na zmieniające się warunki życia i funkcjonowania społeczeństw. Szczególna rola nauki na początku XXI wieku wiąże się z obowiązującym paradygmatem postindustrialnej gospodarki opartej na wiedzy, w której innowacyjność odgrywa kluczową rolę. Dlatego też nakłady na finansowanie działalności naukowej i badawczo-rozwojowej w krajach rozwiniętych stanowią obecnie istotny element budżetów zarówno organizacji państwowych, jak również prywatnych przedsiębiorstw. Rola finansowania prac badawczych w stymulowaniu innowacyjności i rozwoju została doceniona np. w dokumentach Unii Europejskiej (np. Strategia lizbońska, Europa 2020), sugerujących sygnatariuszom odpowiedni poziom wydatków na sektor naukowy i prace B+R (Wieloński, 2003).

W tym samym czasie polska gospodarka jest zaliczana do najmniej innowacyjnych w Unii Europejskiej, zaś całkowite nakłady na działalność naukową i badawczo-rozwojową nie przekraczają 1\% PKB. Wieloletnie niedofinansowanie oraz odcięcie od przodujących ośrodków naukowych świata w okresie socjalizmu, skutkujące technicznym i mentalnym zapóźnieniem wielu dziedzin nauki, miały negatywny wpływ na polski sektor naukowy.

Niewielka skala zaangażowania sektora prywatnego w finansowanie prac badawczych czyni administrację państwową podstawowym fundatorem badań naukowych. Obok mechanizmów finansowania z budżetu państwa (Ministerstwo Nauki, Narodowe Centrum Nauki, Narodowe Centrum Badań i Rozwoju) istotną uzupełniającą rolę odgrywają również środki pomocowe Unii Europejskiej, wykorzystywane w ramach Regionalnych Programów Operacyjnych, Programu Operacyjnego Infrastruktura i Środowisko oraz Programu Operacyjnego Innowacyjna Gospodarka (POIG). Środki ostatniego z wymienionych programów stanowią większość funduszy europejskich uzupełniających budżetowe finansowanie 
sektora naukowego, dlatego też poznanie ich przestrzennej i sektorowej dystrybucji oraz kierujących nimi prawidłowości stanowi najważniejszy cel niniejszej pracy.

Jako podstawowe źródło danych wykorzystano publikowaną przez Ministerstwo Rozwoju Regionalnego bazę beneficjentów POIG, aktualizowaną 30 września 2012, obejmującą wszystkie umowy zawarte od początku funkcjonowania Programu (2007). Analiza danych zawartych w bazie umożliwiła poznanie m.in. liczby i wartości projektów i dofinansowań, lokalizacji beneficjentów oraz struktury projektów ze względu na dziedzinę nauki. Oprócz tego przeprowadzono kwerendę źródeł internetowych w celu zebrania informacji na temat najważniejszych projektów realizowanych przez beneficjentów (studia przypadku). Uzyskane wyniki odniesiono do najważniejszych koncepcji teoretycznych dotyczących finansowania badań naukowych (a zwłaszcza tzw. badań podstawowych) i ich wpływu na innowacyjność gospodarki (np. modelu linearnego) oraz opracowań ukazujących najważniejsze błędy i pułapki finansowania nauki w dawnych krajach socjalistycznych.

\section{PogLĄDY NA FINANSOWANIE NAUKI}

Klasyfikacja badań naukowych ze względu na ich praktyczną użyteczność jest jednym $\mathrm{z}$ podstawowych podziałów funkcjonujących np. w statystykach finansowania sektora naukowego. $Z$ tego względu badania naukowe dzieli sie na:

- podstawowe - mające na celu poszerzenie wiedzy z danej dziedziny, nieniosące ze sobą żadnych zakładanych zastosowań praktycznych;

- aplikacyjne - zakładające zdobycie nowej wiedzy, mającej określone praktyczne zastosowanie; wynikami tego typu badań są modele próbne wyrobów, procesów czy metod;

- prace rozwojowe - wykorzystujące istniejącą już wiedzę (zdobytą w wyniku badań podstawowych lub aplikacyjnych) do opracowania nowych lub istotnie ulepszonych materiałów, urządzeń, wyrobów, procesów, systemów lub usług.

Prezentowany podział wynika z dokumentów międzynarodowych (Frascati Manual 2002, 2003) i został zaadaptowany przez państwowe jednostki statystyczne i administracyjne krajów rozwiniętych. W dużej części jest on oparty na linearnym modelu innowacyjności, teoretycznej koncepcji wpływu badań naukowych na postęp i innowacyjność, opracowanej równolegle przez kilku autorów (m.in. V. Bush, W.R. MacLaurin, M. Holland) w pierwszej połowie XX wieku (Godin, 2011).

Podstawowe założenie modelu linearnego jest takie, iż poszerzenie wiedzy na skutek prowadzonych badań podstawowych ułatwia badania aplikacyjne, a te z kolei prowadzą do powstawania licznych prac rozwojowych, przekładających się na konkretne innowacje, przyspieszające postęp w gospodarce. Dlatego też odpowiednie finansowanie badań podstawowych, prowadzonych głównie przez państwowe jednostki badawcze (np. uczelnie wyższe) przekłada się na wzrost innowacyjności całej gospodarki i przyśpieszenie tempa postępu (Godin, 2006). W późniejszym okresie model objął również kolejne stadia rozwoju innowacji, łącznie z dyfuzją i produkcją. 


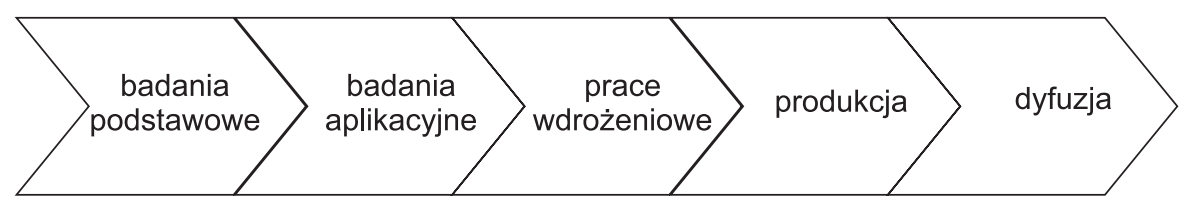

Ryc. 1. Etapy linearnego modelu innowacyjności

Źródło: opracowanie własne na podstawie Godin, 2006

Podstawową cechą modelu, wynikającą z samej jego istoty, jest linearność, z góry zakładająca wyłącznie jednokierunkowy przepływ wiedzy i informacji. Wynika z tego, że finansowanie badań podstawowych bezpośrednio wpływa na poziom i tempo prac rozwojowych i wdrożeniowych, ale prace wdrożeniowe i aplikacyjne nie wpływają na poziom rozwoju badań podstawowych.

Ze względu na linearność oraz tendencję do upraszczania skomplikowanych procesów decydujących o wpływie sektora naukowego na innowacyjność model standardowy od lat 60. XX w. poddawany był częstej krytyce (Balconi i in., 2008). Prostota oraz sugestywność modelu, umożliwiająca łatwe zastosowanie w statystyce oraz analizach na potrzeby politycznych gremiów decyzyjnych, spowodowały jednak jego rozpowszechnienie w instytucjach państwowych (np. National Science Foundation w USA) i statystycznych, czego najlepszym dowodem jest oparcie na jego założeniach Podręcznika Frascati OECD, do dziś stosowanego do statystycznych pomiarów innowacyjności w krajach rozwiniętych (Godin, 2006).

W założeniach modelu linearnego podkreśla się znaczenie odpowiedniego poziomu finansowania badań podstawowych dla innowacyjności i postępu. Podobne założenia można znaleźć również w innych pracach, czerpiących z odmiennych koncepcji teoretycznych np. analizy popytu i podaży innowacyjności (Sarewitz, Pielke, 2007). Synteza poglądów na wpływ finansowania badań podstawowych na innowacyjność, dokonana przez Saltera i Martina (2001), również potwierdza wcześniej przedstawione wnioski. Autorzy wyróżniają kilka rodzajów korzyści z publicznie finansowanych badań podstawowych:

- badania podstawowe są źródłem nowej wiedzy i metodologii;

- umiejętności nabyte przez osoby prowadzące badania (wiedza ukryta - tacit knowledge) są często wykorzystywane w dalszej karierze;

- uczestniczący w badaniach często stają się członkami formalnych i nieformalnych sieci społecznych, łączących ekspertów w danej dziedzinie;

- uczestnictwo w projektach badawczych uczy rozwiązywania skomplikowanych problemów, co jest przydatne również w gospodarce;

- zespoły badawcze mogą tworzyć przedsiębiorstwa typu spin-off.

Badania podstawowe są także niezbędnym elementem systemu innowacyjności w krajach rozwiniętych, umożliwiającym przyswajanie i adaptację innowacji tworzonych w innych krajach (Salter, Martin, 2001).

W ostatnich latach przeprowadzono kilka prób oszacowania stopy zwrotu z publicznie finansowanych badań podstawowych. Jako stopę zwrotu rozumiano fundusze zaoszczędzone przez gospodarkę i administrację dzięki innowacjom bezpośrednio wynikającym z postępów 
w badaniach podstawowych. Szacunkowe wartości stopy zwrotu zamykały się w przedziale 20-35\%, w zależności od przyjętych przez autorów badań metod (Mansfield, 1991; Salter, Martin, 2001).

Świadomość niedostatków modelu linearnego była jednym z powodów opracowania szeregu alternatywnych modeli powiązań badań naukowych i innowacyjności, uwzględniających skomplikowane, wielostronne relacje rozmaitych podmiotów mających wpływ na postęp (jak np. model ekologiczny). Ze względu na duży stopień skomplikowania żaden z alternatywnych modeli innowacyjności nie zdobył jednak podobnej jak model linearny popularności wśród decydentów czy jednostek administracyjnych i statystycznych (Godin, 2006).

\section{Finansowanie sektora naukowego w Polsce}

W opracowanym przez Główny Urząd Statystyczny raporcie Nauka i technika w 2010 (2012) szacuje się całkowite wydatki na badania i rozwój w Polsce (gross expenditure on $R \& D, G E R D)$ na $10 \mathrm{mld} 416 \mathrm{mln}$ zł. Kwota ta stanowi $0,74 \%$ PKB i jest jedną z najniższych w krajach UE (20. miejsce na 27 krajów członkowskich). 73\% z powyższej kwoty stanowiło finansowanie ze środków publicznych - budżetowych oraz środków państwowych wyższych uczelni. Jednocześnie prawie 40\% środków przeznaczone było na finansowanie badań podstawowych, ponad 20\% - badań aplikacyjnych, a 39\% - prac wdrożeniowych. Klasyfikacja wydatków ze względu na dziedziny nauki ujawnia dominację nauk technicznych (ponad $46 \%$ wszystkich funduszy), przyrodniczych (24\%) oraz medycznych (10\%). Nauki rolnicze otrzymały ponad $7 \%$ całości finansowania, nauki społeczne $-6 \%$, a humanistyczne $-4 \%$.

\section{SEKTOR NAUKOWY W KRAJACH WYSOKO ROZWINIĘTYCH}

Założenia zarówno Strategii lizbońskiej, jak i obecnie wprowadzonej w jej miejsce Strategii Europa 2020 sugerują państwom członkowskim UE udział wydatków na badania i rozwój wynoszący co najmniej 3\% PKB, co ma umożliwić dorównanie przodującym w tej dziedzinie krajom - USA i Japonii. Wysokie nakłady na prace badawcze, oscylujące wokół 3\% PKB, są charakterystyczną cechą finansowania prac badawczych w krajach rozwiniętych.

Kolejnym ważnym elementem jest również sama struktura finansowania, a zwłaszcza wysoki odsetek środków prywatnych, często przekraczający 50\% całkowitych nakładów (np. w przypadku Japonii - 76\%, Niemiec - 68\%, Finlandii - 67\% - dane z 2009 r.). W tym przypadku wspomniane dokumenty strategiczne UE sugerowały poziom prywatnych nakładów badawczych na co najmniej 2/3 całości środków (Rozmus, Cyran, 2009).

$\mathrm{Z}$ wysokim udziałem środków prywatnych w finansowaniu działalności badawczej naturalnie wiąże się silna relacja na linii nauka-gospodarka. Dotyczy to zarówno prywatnych ośrodków badawczych, prowadzących badania aplikacyjne i wdrożeniowe, jak również państwowych (uniwersyteckich i innych) centrów naukowych, skupionych na badaniach podstawowych. 
Tab. 1. Nakłady na prace badawcze w krajach Unii Europejskiej

\begin{tabular}{|l|c|}
\hline \multicolumn{1}{|c|}{ Państwo } & $\begin{array}{c}\text { Nakłady } \\
\text { jako odsetek PKB (2011) }\end{array}$ \\
\hline Unia Europejska & 2,03 \\
\hline Finlandia & 3,78 \\
\hline Szwecja & 3,37 \\
\hline Dania & 3,09 \\
\hline Niemcy & 2,84 \\
\hline Austria & 2,75 \\
\hline Słowenia & 2,47 \\
\hline Estonia & 2,38 \\
\hline Francja & 2,25 \\
\hline Belgia & 2,04 \\
\hline Holandia & 2,04 \\
\hline Czechy & 1,84 \\
\hline Wielka Brytania & 1,77 \\
\hline Irlandia & 1,72 \\
\hline Portugalia & 1,50 \\
\hline Luksemburg & 1,43 \\
\hline Hiszpania & 1,33 \\
\hline Włochy & 1,25 \\
\hline Węgry & 1,21 \\
\hline Litwa & 0,92 \\
\hline Polska & $\mathbf{0 , 7 7}$ \\
\hline Chorwacja & 0,75 \\
\hline Malta & 0,73 \\
\hline Łotwa & 0,70 \\
\hline Słowacja & 0,68 \\
\hline Bułgaria & 0,57 \\
\hline Cypr & 0,48 \\
\hline Rumunia & 0,48 \\
\hline & \\
\hline & \\
\hline
\end{tabular}

Źródło: Eurostat

Ważnym elementem współpracy na linii nauka-gospodarka jest tworzenie akademickich firm typu spin-off. W przypadku krajów rozwiniętych jest to popularna forma komercjalizacji wyników badań naukowych. Według ustaleń Landry’ego i in. (2006), dotyczących tej formy aktywności gospodarczej naukowców w Kanadzie, 12\% badaczy specjalizujących się w naukach biologicznych prowadzi własną firmę typu spin-off. Wyniki badań przeprowadzonych rok później wśród naukowców wydziałów Biochemii, Biofizyki i Biotechnologii oraz Biologii i Nauk o Ziemi UJ (Raport na temat..., 2007) wskazują, iż zaledwie 5\% ankietowanych polskich naukowców w jakikolwiek sposób (np. sprzedaż licencji) skomercjalizowało wyniki swoich badań, zaś odsetek naukowców prowadzących własne firmy jest mniejszy niż 1\%. 
Tab 2. Liczba wniosków do EPO (tylko kraje pow. 100 wniosków)

\begin{tabular}{|l|c|}
\hline \multicolumn{1}{|c|}{ Państwo } & $\begin{array}{c}\text { Liczba wniosków } \\
\text { patentowych do EPO } \\
(2010)\end{array}$ \\
\hline Niemcy & 21880 \\
\hline Francja & 8751 \\
\hline Wielka Brytania & 4795 \\
\hline Włochy & 4443 \\
\hline Holandia & 3236 \\
\hline Szwecja & 2879 \\
\hline Austria & 1581 \\
\hline Hiszpania & 1458 \\
\hline Belgia & 1412 \\
\hline Dania & 1350 \\
\hline Finlandia & 1167 \\
\hline Irlandia & 353 \\
\hline Polska & $\mathbf{3 0 8}$ \\
\hline Czechy & 270 \\
\hline Węgry & 203 \\
\hline Słowenia & 165 \\
\hline Portugalia & 110 \\
\hline
\end{tabular}

Źródło: Eurostat

Podobną sytuację ujawnia analiza wniosków patentowych do Europejskiego Urzędu Patentowego, w której Polska zajmuje jedno z ostatnich miejsc. 308 wniosków złożonych przez polskich naukowców sytuuje nasz kraj na czele nowych krajów UE, jednakże pomimo różnic w liczbie ludności i potencjału naukowego różnica dzieląca Polskę od pozostałych krajów Europy Środkowej jest minimalna. Jednocześnie różnice dzielące Polskę od nawet mniejszych krajów starej Unii są znacznie większe.

\section{Program Operacyjny InNOWACyjna Gospodarka}

Program Operacyjny Innowacyjna Gospodarka (POIG) wystartował w 2007 roku, kiedy komisarz ds. rozwoju regionalnego UE podpisała decyzję Komisji Europejskiej przyjmującą program do realizacji. 30 października 2007 roku Rada Ministrów RP uchwałą przyjęła POIG do realizacji. Jest to jeden z 6 programów krajowych realizowanych ze środków unijnych, skierowany głównie do przedsiębiorców decydujących się na innowacyjne projekty, jak również do instytucji naukowych, badawczych i otoczenia biznesu. Jego ramy czasowe obejmują lata 2007-2013, a suma środków przeznaczonych na dofinansowanie wynosi 10,186 mld euro, w tym 8,658 mld pochodzi z Europejskiego Funduszu Rozwoju Regionalnego (EFRR), a pozostałe 1,527 mld z polskiego budżetu. Ponad 90\% funduszy przeznaczonych jest na działania typu: badania + rozwój $(B+R)$, innowacje, technologie 
informacyjne i komunikacyjne (www.poig.gov.pl). W założeniu podział środków według beneficjentów wygląda następująco: przedsiębiorcy - 56\%, jednostki naukowe $-23 \%$, administracja i obywatele $-18 \%$, instytucje otoczenia biznesu $-3 \%$.

Oprócz bezpośredniego wsparcia realizowanych projektów POIG ma też współfinansować działania systemowe wspierające rozwój innowacyjnej gospodarki, w tym dla instytucji otoczenia biznesu takich jak inkubatory przedsiębiorczości czy parki technologiczne. Wsparcie innowacyjności ma być niezależne od sektora czy konkretnej branży - muszą to być jednak projekty innowacyjne na poziomie krajowym lub międzynarodowym. Lokalną innowacyjność mają wspierać fundusze przyznawane w ramach Regionalnych Programów Operacyjnych. Programem zarządza Ministerstwo Rozwoju Regionalnego, a wspierać je mają instytucje pośredniczące: Ministerstwo Gospodarki, Narodowe Centrum Badań i Rozwoju (do końca sierpnia 2011 roku funkcję tę pełniło Ministerstwo Nauki i Szkolnictwa Wyższego) oraz Ministerstwo Administracji i Cyfryzacji (do listopada 2011 roku funkcję tę pełniło Ministerstwo Spraw Wewnętrznych i Administracji).

Głównym celem POIG na lata 2007-2013 jest rozwój polskiej gospodarki oparty na innowacyjnych przedsiębiorstwach (www.poig.gov.pl). Został on sformułowany na podstawie założeń Strategii lizbońskiej zaktualizowanej w 2005 roku. Wśród celów szczegółowych dwa dotyczą bezpośrednio uczelni i ośrodków badawczo-naukowych (www.poig.gov.pl):

- Wzrost konkurencyjności polskiej nauki;

- Zwiększenie roli nauki w rozwoju gospodarczym.

Fundusze zostały podzielone na 9 osi priorytetowych:

1. Badania i rozwój nowoczesnych technologii.

2. Infrastruktura sfery $\mathrm{B}+\mathrm{R}$.

3. Kapitał dla innowacji.

4. Inwestycje w innowacyjne przedsięwzięcia.

5. Dyfuzja Innowacji.

6. Polska gospodarka na rynku międzynarodowym.

7. Społeczeństwo informacyjne - budowa elektronicznej administracji.

8. Społeczeństwo informacyjne - zwiększanie innowacyjności gospodarki.

9. Pomoc techniczna.

Dwie pierwsze osie skierowane są bezpośrednio do sektora naukowego, a ich głównymi celami jest wzmocnienie roli nauki w polskiej gospodarce przez wsparcie działań $\mathrm{B}+\mathrm{R}$ oraz podniesienie jej konkurencyjności przez konsolidację i modernizację infrastruktury badawczej i informatycznej wiodących uczelni wyższych. Na projekty realizowane w ramach pierwszej osi zarezerwowano 14,9\% środków POIG, a w ramach drugiej osi 12,8\%. Instytucją wdrażającą obie osie jest Narodowe Centrum Badań i Rozwoju. Uczelnie i instytucje naukowo-badawcze realizują też projekty w ramach pozostałych osi (27 projektów na łączną kwotę dofinansowania $431 \mathrm{mln}$ zł).

Do grudnia 2012 roku zatwierdzono 12865 projektów na 39,21 mld zł. Oznacza to wykorzystanie ponad 90\% środków przeznaczonych na program. W ramach osi 1 i 2 podpisano 1387 projektów na łączną sumę 11,32 mld zł (www.poig.gov.pl). 


\section{FINANSOWANIE SEKTORA NAUKOWEGO ZE ŚRODKÓW POIG}

Na podstawie udostępnionej przez Ministerstwo Rozwoju Regionalnego bazy beneficjentów (stan na 30 IX 2012) wyliczono 511 projektów realizowanych przez uczelnie wyższe i jednostki naukowe. Wzięto pod uwagę również projekty realizowane przez Fundację na Rzecz Nauki Polskiej oraz firmy założone i prowadzone przez uczelnie. Średnia wartość realizowanego projektu wynosi 19,85 $\mathrm{mln}$ zł, w tym dofinasowania 18,56 mln zł. Łącznie dofinansowanie sektora naukowego z POIG na mocy podpisanych umów wynosi $8260 \mathrm{mln}$ zł, co obrazuje tabela 3 .

Tab 3. Udział instytucji naukowych w podziale środków POIG

\begin{tabular}{|l|c|c|}
\hline \multicolumn{1}{|c|}{ Beneficjenci } & $\begin{array}{c}\text { Suma przyznanych } \\
\text { dotacji (zł) }\end{array}$ & $\begin{array}{c}\text { Udział } \\
(\%)\end{array}$ \\
\hline Uczelnie wyższe & 3637871010 & 13,3 \\
\hline Jednostki naukowe & 3391059331 & 12,4 \\
\hline Podmioty specjalistyczne & 1231000000 & 4,5 \\
\hline Pozostali beneficjenci & 19123257063 & 69,8 \\
\hline Razem & 27383187404 & 100 \\
\hline
\end{tabular}

Uwaga: wartości dotyczą jedynie projektów z podpisanymi umowami o dofinansowaniu

Źródło: www.poig.gov.pl

Fundusze zostały rozdysponowane na projekty z różnych dziedzin nauki (ryc. 2). Niemal połowę środków $(49,8 \%)$ przeznaczono na nauki przyrodnicze, w tym głównie biologiczne i medyczne, 36\% środków przekazano na realizację projektów z zakresu nauk technicznych - głównie materiałoznawstwa, IT i energetyki. Jedynie 1,8\% środków przekazano na nauki humanistyczne. Ze względu na przeznaczenie realizowanych projektów można rozróżnić trzy podstawowe zakresy: infrastrukturę, prace $\mathrm{B}+\mathrm{R}$ oraz projekty otoczenia i wsparcia nauki. Zdecydowanie największe są projekty infrastrukturalne, gdzie średnia wartość projektu wynosi ponad $64 \mathrm{mln}$ zł, podczas gdy średnia wartość pozostałych oscyluje koło $10 \mathrm{mln}$ zł. Inwestycje w infrastrukturę wymagają największych nakładów, dlatego 80 realizowanych z tego zakresu projektów obejmuje równo 50\% wartości wszystkich projektów. Wśród nich znajdują się największe realizacje dofinansowane z POIG. Prace B+R obejmują $48 \%$ środków i stanowią najliczniejszą grupę (414 projektów). Najmniej liczną grupę stanowią projekty otoczenia i wsparcia nauki obejmujące $2 \%$ środków. 


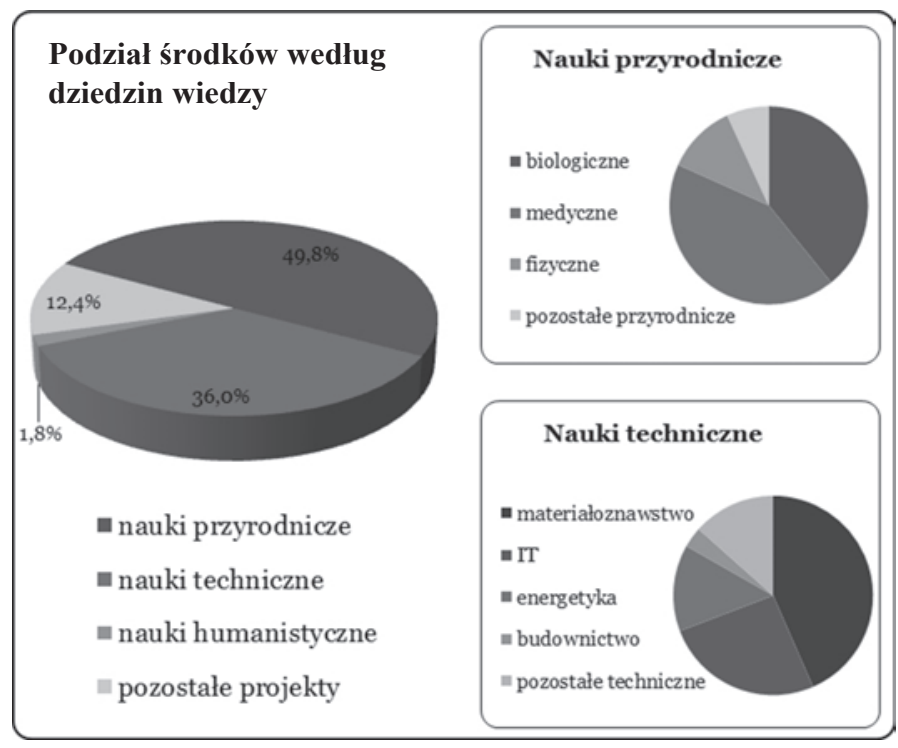

Ryc. 2. Struktura finansowania nauki z POIG

Źródło: opracowanie własne na podstawie bazy beneficjentów POIG

Wyszczególnione z bazy POIG 511 projektów realizowanych jest przez 155 beneficjentów (w tym 103 realizujących projekty o wartości ponad $10 \mathrm{mln}$ zł). Największym projektem jest Wrocławskie Centrum Badań (EIT+) (wartość projektu wynosi $611 \mathrm{mln}$ zł, w tym dofinansowanie $503 \mathrm{mln}$ zł). Jest to remont i rozbudowa kampusu Pracze. Powstają tu nowoczesne laboratoria, gdzie prowadzone będą interdyscyplinarne badania (udziałowcami EIT+ są największe wrocławskie uczelnie oraz samorząd miejski). Najwięcej projektów (27) realizuje krakowska Akademia Górniczo-Hutnicza. Są one jednak mniejsze - ich średnia wartość wynosi 15,3 mln zł, przez co wyższą wartość sumaryczną projektów osiągnęły 4 instytucje (ryc. 3). Widać z tego, że liczba realizowanych projektów nie zawsze przekłada się na wielkość uzyskanego dofinansowania. Dobrze obrazuje to zestawienie Uniwersytetów Jagiellońskiego i Warszawskiego, które otrzymują niemal identyczne dofinansowanie, realizując różną liczbę projektów (UJ - 20, UW - 7). Różnice te wynikają zarówno z charakteru samych inwestycji, jak i przyjętej taktyki realizowania kilku mniejszych projektów lub koncentracji na pojedynczych dużych. 


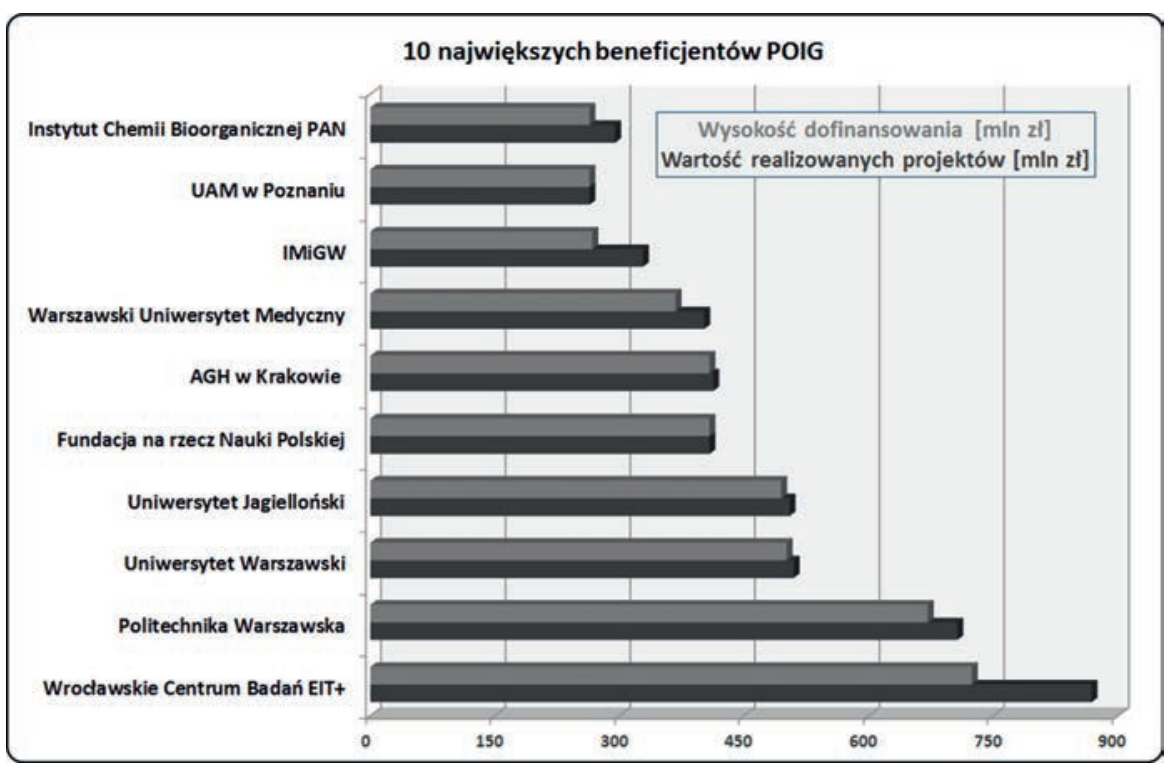

Ryc. 3. 10 największych beneficjentów POIG

Źródło: opracowanie własne na podstawie bazy beneficjentów POIG

Rozmieszczenie przestrzenne beneficjentów i realizowanych przez nich projektów jest bardzo nierównomierne. Beneficjenci pochodzą z 32 miejscowości. Są to największe miasta i zarazem duże ośrodki akademickie oraz kilka mniejszych miejscowości, gdzie zlokalizowane są pojedyncze instytucje naukowo-badawcze (ryc. 4.).

Na podstawie liczby beneficjentów, realizowanych projektów i ich wartości wydzielić można kilka kategorii ośrodków. Do pierwszej należy Warszawa - zdecydowanie wyróżniająca się na tle reszty kraju. Koncentruje 1/3 beneficjentów oraz 177 projektów o wartości 4219 mln zł. Pozycja stolicy opiera się nie tylko na silnym ośrodku akademickim, ale też na lokalizacji centralnych instytucji jak Instytut Meteorologii i Gospodarki Wodnej, realizujących często projekty obejmujące cały kraj. W bezpośrednim sąsiedztwie Warszawy znajdują się kolejne mniejsze ośrodki badawcze (Otwock, Błonie, Falenty), co również zwiększa dysproporcję w porównaniu z resztą Polski. Drugą kategorią ośrodków są regionalni liderzy (Kraków, Wrocław, Poznań). Są to duże ośrodki akademickie, gdzie realizowanych jest po kilkadziesiąt projektów, których łączna wartość wynosi od $820 \mathrm{mln}$ zł (Poznań) do 1483 mln zł (Kraków). Do trzeciej kategorii zaliczyć można bardziej aktywne ośrodki - skąd zgłosiły się co najmniej trzy różne instytucje realizujące projekty o łącznej wartości ponad 100 mln zł. Są to Łódź, Gliwice, Katowice, Lublin, Gdańsk, Zabrze i Szczecin. Czwartą kategorię stanowią pozostałe aktywne ośrodki, w których realizowanych jest po kilka projektów lub pojedynczy duży jak w Kielcach i Świerku. Z pozostałych miejscowości pochodzą pojedynczy beneficjenci realizujący przeważnie jeden projekt lub kilka mniejszych o łącznej wartości nieprzekraczającej $10 \mathrm{mln}$ zł. 


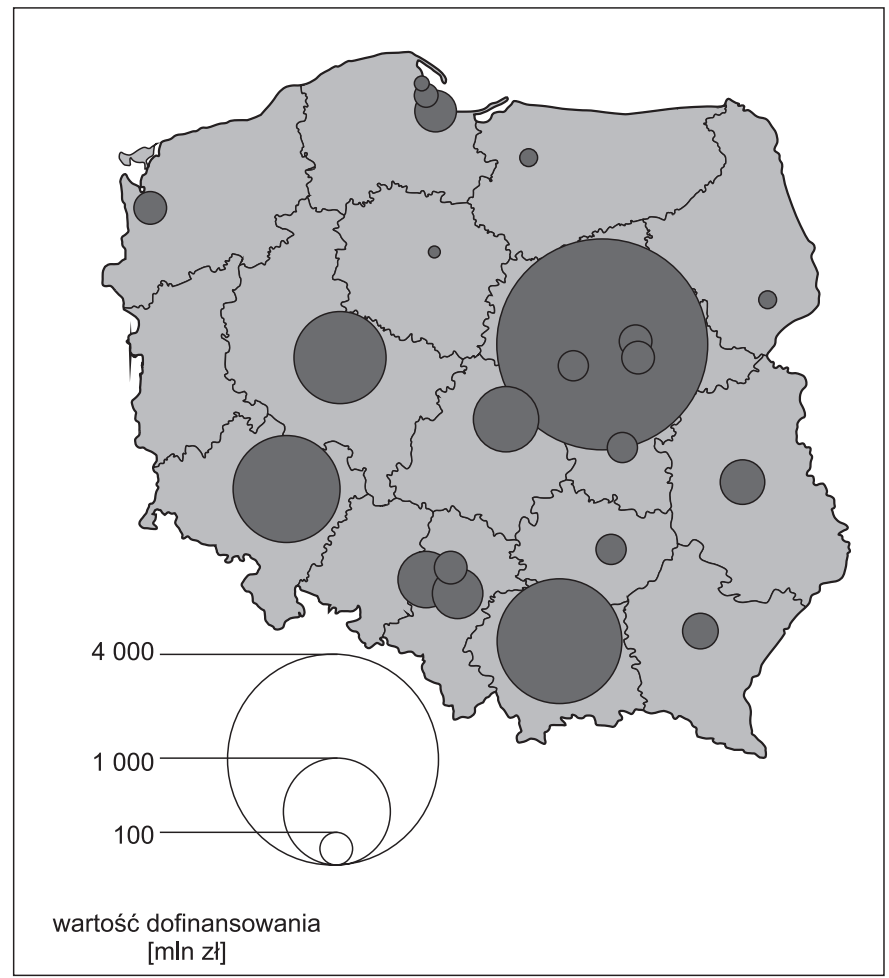

Ryc. 4. Rozmieszczenie projektów dofinansowanych z POIG

Źródło: opracowanie własne na podstawie bazy beneficjentów POIG

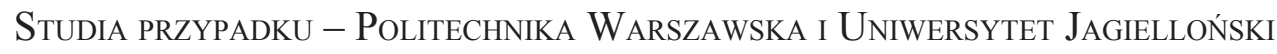

Politechnika Warszawska jest uczelnią, która uzyskała największe łączne dofinansowanie na realizowane projekty. Jest to 16 projektów o łącznej wartości $706 \mathrm{mln}$ zł (średnio 44,1 mln zł), w tym dofinansowanie $670 \mathrm{mln}$ zł (średnio $41,9 \mathrm{mln}$ zł). Ich wartość jest zróżnicowana i wynosi od $2 \mathrm{mln}$ do $385 \mathrm{mln}$ zł (Centrum Zaawansowanych Materiałów i Technologii). Pomimo że przeważają projekty badawcze (oś 1), to zdecydowaną większość środków zajmują 4 inwestycje w infrastrukturę. Projekty z zakresu B+R stanowią 1/3 wartości uzyskanych środków, a wsparcie innowacyjności jedynie 2\% (ryc. 5). Przy podziale projektów na dziedziny nauki największy udział ma materiałoznawstwo - głównie przez największą z realizowanych inwestycji (wykorzystującą ponad połowę uzyskanych środków). Zdecydowanie mniejsze środki wykorzystywane są na rozwój IT, budownictwa, fizyki i medycyny (ryc. 5). 


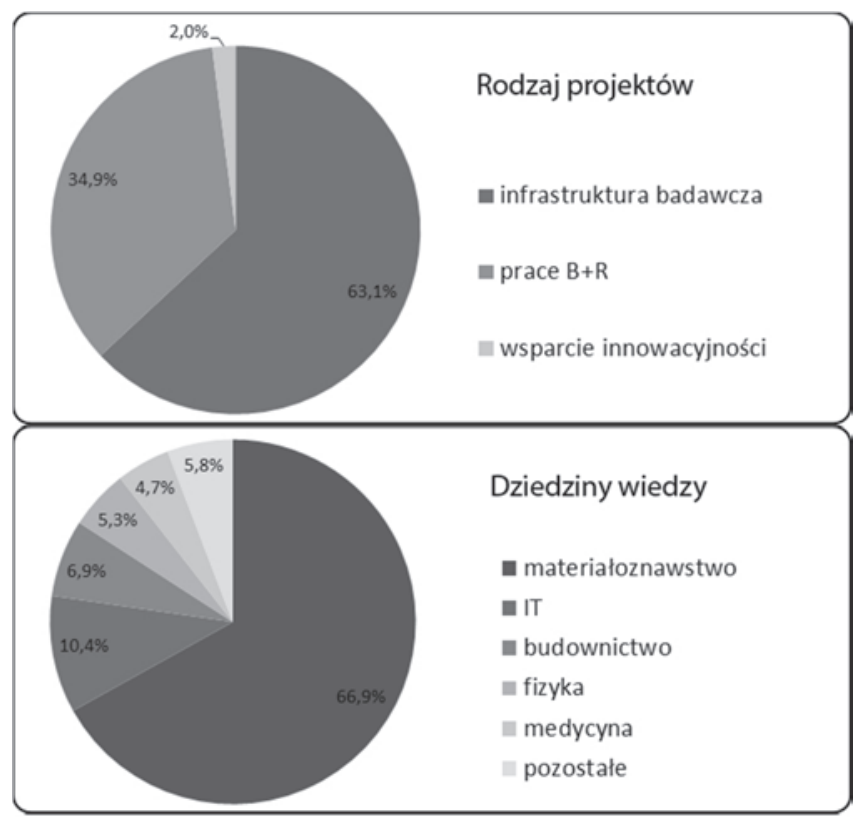

Ryc. 5. Struktura projektów realizowanych ze środków POIG przez Politechnikę Warszawską

Źródło: opracowanie własne na podstawie bazy beneficjentów POIG

Trochę inną strategię przyjął Uniwersytet Jagielloński, realizując większa liczbę mniejszych projektów (20) o łącznej wartości $504 \mathrm{mln}$ zł (średnio 25,2 mln zł), w tym dofinansowanie wynosi $494 \mathrm{mln}$ zł (średnio 24,7 mln zł). Dodatkowo jeden z projektów realizowany jest nie przez sam Uniwersytet, ale przez założoną przez niego firmę. Największy z realizowanych projektów ma wartość $152 \mathrm{mln}$ zł (Narodowe Centrum Promieniowania Elektromagnetycznego). Równocześnie Uniwersytet uzyskał dofinansowane na wiele małych projektów o wartości rzędu 100 tys. zł. Są to głównie konkretne badania z zakresu fizyki, medycyny i biotechnologii. Podobnie jak w przypadku PW większość środków przeznaczona jest na rozwój infrastruktury, a około 1/3 stanowi wsparcie badań (ryc. 6). Warto jednak zwrócić uwagę na Jagiellońskie Centrum Innowacji - spółkę założoną przez Uniwersytet i realizującą jeden duży projekt (rozbudowa Jagiellońskiego Parku i Inkubatora Technologii - Life Science) o wartości $126 \mathrm{mln}$ zł (dofinansowanie wynosi $84 \mathrm{mln}$ zł). Jeśli doliczymy tę inwestycję, udział projektów infrastrukturalnych jest jeszcze większy. Istotne zróżnicowanie widać w strukturze środków wykorzystywanych w rożnych dziedzinach wiedzy. Największy udział mają projekty związane z fizyką (głównie przez największą z inwestycji), ale też znaczący udział mają nauki medyczne i biologiczne. 


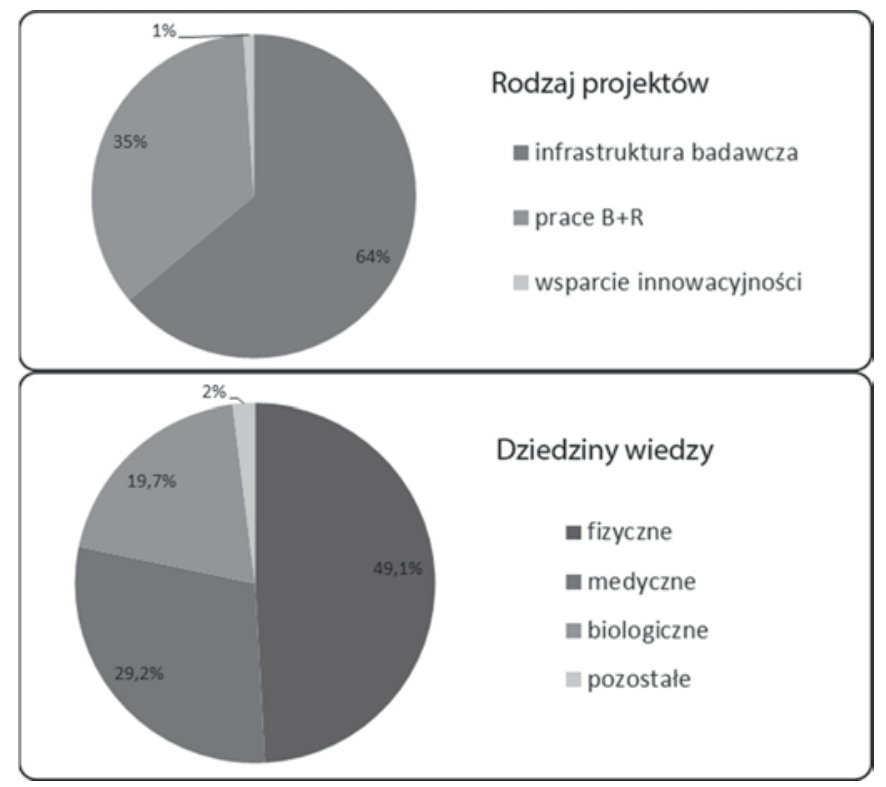

Ryc. 6. Struktura projektów realizowanych ze środków POIG przez Uniwersytet Jagielloński

Źródło: opracowanie własne na podstawie bazy beneficjentów POIG

\section{DYSKUSJA I WNIOSKI}

Finansowanie projektów innowacyjnych w krajach przechodzących transformację, nawet w przypadku skoku ilościowego (jak np. w Estonii), często napotyka na bariery związane ze złą alokacją funduszy, a wynikające m.in. z określonych ram światopoglądowych decydentów, braku zrozumienia funkcjonowania sektora naukowego w warunkach gospodarki rynkowej czy też warunków społecznych i ekonomicznych istniejących w danym kraju. Wśród najważniejszych tego typu barier można wyliczyć m.in. (Varblane i in., 2007):

- niedocenianie roli sektora publicznego i wiarę w niewidzialną rękę rynku rozwiązującą wszelkie (również niezwiązane z ekonomią) problemy;

- dominującą pozycję modelu linearnego i niedocenianie popytu na innowacje;

- przeciwstawianie sobie sektorów innowacyjnych i tradycyjnych;

- przecenianie roli bezpośrednich inwestycji zagranicznych jako źródła innowacji;

- brak kapitału społecznego, ograniczający dyfuzję innowacyjnych rozwiązań.

Do podobnych wniosków dochodzą również autorzy krajowi (np. Borowiec, 2011; Gierańczyk, 2010).

Przeprowadzona analiza wydatkowania funduszy POIG wskazuje na tendencję do powielania niektórych z wymienionych błędów. Stosunkowo niewielka liczba projektów wdrożeniowych, najczęściej ograniczających się do finansowania ochrony patentowej, świadczy o dominacji finansowania badań podstawowych. Brak występowania w programie konsorcjów 
złożonych z instytucji naukowych i przedstawicieli sektora przedsiębiorstw dowodzi słabych połączeń na linii nauka-gospodarka, a także niedoceniania wywołanego przez przedsiębiorstwa popytu na stymulowanie innowacyjności sektora naukowego.

Kolejnym przykładem jest charakterystyczna dominacja wśród finansowanych projektów dwóch dziedzin nauki: materiałoznawstwa oraz nauk biologicznych (a także w mniejszym stopniu technologii informacyjnych i komunikacyjnych), postrzeganych jako działalność high-tech, przy niewielkiej liczbie projektów zakładających wdrożenie innowacji i modernizację w sektorach tradycyjnych (np. górnictwo węglowe).

Program Operacyjny Innowacyjna Gospodarka stał się podstawowym źródłem finansowania wielkiej infrastruktury badawczej, obejmującej najbardziej nowoczesne, skomplikowane i kosztowne urządzenia naukowe. Biorąc pod uwagę, iż prawie połowa środków Programu jest przeznaczona na powyższy cel, a średnia wartość projektu z tej dziedziny wynosi ponad $60 \mathrm{mln}$ zł, warto zadać pytanie o efektywność wykorzystania zakupionego sprzętu, związaną np. z liczbą etatów badaczy w instytucjach uzyskujących wsparcie.

Ważnym zjawiskiem jest również koncentracja przestrzenna beneficjentów Programu, w dużej mierze ograniczających się do przodujących jednostek badawczych w Polsce. Biorąc pod uwagę znaczne różnice pomiędzy poziomem naukowym uczelni wyższych i jednostek badawczych w Polsce (mierzone np. liczbą publikacji w czasopismach Listy Filadelfijskiej), można zaryzykować twierdzenie, iż przyznane fundusze przyczynią się do umocnienia pozycji największych i najsilniejszych jednostek, zaś korzyści dla instytucji położonych peryferyjnie są minimalne.

\section{Literatura}

Balconi, M., Brusoni S., Orsenigo, L. (2008). In Defence of the Linear Model: An Essay. KITeS Working Papers, 216.

Borowiec, M. (2011). Zmiany kierunków kształcenia akademickiego w Polsce. Prace Komisji Geografii Przemystu Polskiego Towarzystwa Geograficznego, 18, 9-22.

Gierańczyk, W. (2010). Rola własności intelektualnej w budowaniu innowacyjności krajów Unii Europejskiej. Prace Komisji Geografii Przemystu Polskiego Towarzystwa Geograficznego, 16, 76-86.

Godin, B., 2006. The Linear Model of Innovation: The Historical Construction of an Analytical Framework. Science, Technology \& Human Values, 31(6), 639-667.

Godin, B. (2011). The Linear Model of Innovation: Maurice Holland and the Research Cycle. Social Science Information, 50, 569-58.

Landry, R., Amara, N., Rherrad, I. (2006). Why Are Some University Researchers More Likely to Create Spin-offs Than Others? Evidence from Canadian Universities. Research Policy, 35, 1599-1615.

Mansfield, E. (1991). Academic Research and Industrial Innovation. Research Policy, 20, 1-12.

Nauka i technika w 2010 (2012). Warszawa: Główny Urząd Statystyczny.

Rozmus, A., Cyran, K. (2009). Finansowanie działalności badawczo-rozwojowej w Polsce i innych krajach - diagnoza i próba oceny. e-Finanse, 4.

Salter, A., Martin, B. (2001). The Economic Benefits of Publicly Funded Scientific Research: A Critical Review. Research Policy, 30, 509-532.

Sarewitz, D., Pielke, R. (2007). The Neglected Heart of Science Policy: Reconciling Supply and Demand for Science. Environmental Science and Policy, 10, 5-16. 
Varblane, U., Dyker, D., Tamm, D., Tunzlemann, N. (2007). Can the National Innovation Systems of the New EU States be Improved? Post-Communist Economies, 19(4), 399-416.

Wieloński, A. (2003). Przemysł nowej gospodarki. Prace Komisji Geografii Przemystu Polskiego Towarzystwa Geograficznego, 6, 21-25.

Piotr Dawidko, mgr, Uniwersytet Jagielloński, Instytut Geografii i Gospodarki Przestrzennej. Autor jest doktorantem w Zakładzie Rozwoju Regionalnego IGiGP UJ. Jego zainteresowania badawcze obejmują m.in. funkcjonowanie sektorów wysokich technologii, zagadnienia regionalnego i lokalnego uzależnienia od ścieżki, a także przestrzennego zróżnicowania innowacyjności i czynników na nie wpływających.

Piotr Dawidko, the author is a $\mathrm{PhD}$ student at the Institute of Geography and Spatial Management at the Jagiellonian University. His scientific interests encompass e.g. functioning of high-technology industries, local and regional path dependence and spatial diversification of innovativeness and factors shaping it.

Adam Górka, mgr, Uniwersytet Jagielloński, Instytut Geografii i Gospodarki Przestrzennej. Autor jest doktorantem w Zakładzie Rozwoju Regionalnego IGiGP UJ. Jego zainteresowania badawcze obejmują szeroko pojętą geografię społeczną, kształtowanie przestrzeni miejskiej, a w szczególności przestrzeni publicznej, rozwój regionalny oraz funkcjonowanie samorządów i działania lokalnych społeczności.

Adam Górka, the author is a PhD student at the Institute of Geography and Spatial Management at the Jagiellonian University. His scientific interests encompass e.g. social geography, city developing (mostly public space), local and regional development, municipal policy and local society activity.

adres/address: Uniwersytet Jagielloński

Instytut Geografii i Gospodarki Przestrzennej

ul. Gronostajowa 7, 30-387 Kraków

e-mail: piotr.dawidko@uj.edu.pl (Piotr Dawidko),ads.gorka@uj.edu.pl (Adam Górka) 